\title{
Effects of Tall Fescue and Its Fungal Endophyte on the Development and Survival of Tawny-Edged Skippers (Lepidoptera: Hesperiidae)
}

\section{Authors: Karin J. Jokela, Diane M. Debinski, and Rebecca L. McCulley}

This is a pre-copyedited, author-produced PDF of an article accepted for publication in Environmental Entomology following peer review. The version of record, see complete citation below, is available online at: http://dx.doi.org/10.1093/ee/nvv151

Jokela, Karin J., Diane M. Debinski, and Rebecca L. McCulley. 2016. Effects of Tall Fescue and Its Fungal Endophyte on the Development and Survival of Tawny-Edged Skippers (Lepidoptera: Hesperiidae) Environmental Entomology, 45(1), 142-149. Available at: http://dx.doi.org/10.1093/ ee/nvv151. 


\title{
Effects of Tall Fescue and Its Fungal Endophyte on the Development and Survival of Tawny-Edged Skippers (Lepidoptera: Hesperiidae)
}

\author{
Karin J. Jokela, ${ }^{1,2}$ Diane M. Debinski, ${ }^{1}$ and Rebecca L. Mcculley ${ }^{3}$ \\ ${ }^{1}$ Ecology, Evolution and Organismal Biology Department at lowa State University, 251 Bessey Hall, Ames, IA 50011 (grimlund@ias- \\ tate.edu), ${ }^{2}$ Corresponding author, e-mail: grimlund@iastate.edu, and ${ }^{3}$ Department of Plant and Soil Sciences, University of \\ Kentucky, Lexington KY 40546 (rebecca.mcculley@uky.edu)
}

\begin{abstract}
Invasive, exotic grasses are increasing in tallgrass prairie and their dominance may be contributing to the decline of grassland butterflies through alterations in forage quality. Tall fescue (Schedonorus arundinaceus (Schreb.) Dumort.), an exotic grass covering millions of acres in the United States, can host a fungal endophyte, Epichloë coenophiala (Morgan-Jones \& Gams). Alkaloids produced by the endophyte are known to be toxic to some foliar-feeding pest insects. Endophyte-infected tall fescue is commonly planted in hayfields, pastures, lawns, and is invading natural areas, but effects of the endophyte on nonpest insects such as butterflies are relatively unknown. Our objective was to investigate the role that tall fescue and its endophyte might play in the decline of grass skippers (Hesperiidae). We examined growth and survival parameters of tawny-edged skippers (Polites themistocles (Latreille)) that were reared on endophyte-infected tall fescue $(\mathrm{E}+$ ), endophyte-free tall fescue $(E-)$, and Kentucky bluegrass (KBG). KBG was included as a comparison because it is a cool season grass known to be palatable to $P$. themistocles larvae. Interestingly, results showed that the endophyte did not affect growth and survival of larvae compared to uninfected tall fescue, even though significant amounts of loline alkaloids (average 740 ppm) were measured in endophyte-infected plant material. Larvae feeding on KBG grew faster with greater survival rates than larvae on both tall fescue treatments. These results confirm that tall fescue invasion and dominance may be deteriorating the quality of grassland habitats for native pollinators; however, this effect does not appear to be linked to endophyte infection.
\end{abstract}

Many of the world's grassland ecosystems are disappearing and undergoing major compositional changes (Ceballos et al. 2010, Veldman and Putz 2011, Parr et al. 2014). North American tallgrass prairie ecosystems have declined in area by $99.9 \%$ since the mid1800s, largely due to the conversion of land for agricultural uses (Samson and Knopf 1994). Much of the grassland habitat remaining globally exists as novel mixtures of exotic and native species on pastures, hayfields, and rangelands (Herkert et al. 1995, Hobbs et al. 2009, Veldman et al. 2015). These changing plant communities affect the distribution and abundance of insect communities associated with grasslands (Jonas et al. 2002). An extreme example exists in New Zealand where the pastures have been largely reduced to one introduced grass species and one species of clover, and the control of insect pests has become increasingly complex due to the simplified landscape (Goldson et al. 2014). In the United States, exotic and pervasive grasses such as tall fescue, Kentucky bluegrass, and smooth brome (Bromus inermis) can account for at least half of the vegetation in some grassland systems (Grant et al. 2009), and these species are likely modifying the activity and viability of local grassland wildlife, including pollinators. For example, tall fescue (Schedonorus arundinaceus (Schreb.), formerly Lolium arundinaceum (Schreb.) Dumort), a Eurasian cool-season grass, covers millions of acres in North America (Fribourg et al. 2001) and is now the most abundant cool-season grass in the eastern United States (Ball et al. 1993, Roberts and Andrae 2004, Rudgers and Clay 2007). Moreover, an estimated $75-80 \%$ of tall fescue in North America is infected with the fungal endophyte Epichloë coenophiala (Morgan-Jones \& Gams) (formerly Neotyphodium coenophialum) (Leuchtmann et al. 2014), which produces alkaloids that cause toxicosis in cattle and are detrimental to insect herbivores (Ball et al. 1993, Roberts and Andrae 2004, Rudgers and Clay 2007).

There are four major classes of alkaloids known to be produced by Epichloë spp., and all of them have been shown to deter at least some types of invertebrates (Cheplick and Faeth 2009). Peramine and loline alkaloids are the most implicated in invertebrate resistance (Clay 1989), though they may operate in different ways 
against insect herbivores (e.g., deterring feeding or decreasing growth and reproduction; Hoveland 1993, Blankenship et al. 2001). In particular, lolines have been associated with lower insect biomass, increased mortality, and longer developmental times (Wilkinson et al. 2000, Jensen et al. 2009). However, results from some studies show that alkaloid effects on invertebrates are somewhat equivocal (Saikkonen et al. 2006), and effects seem to vary across species of herbivores (Crawford et al. 2010). Most negative alkaloid effects come from studies that used generalist pest insects (Siegel et al. 1990, Wilkinson et al. 2000, Braman et al. 2002, Popay and Bonos 2005, Ball et al. 2006, Baldauf et al. 2011, Keathley and Potter 2012). In spite of extensive efforts to describe the role of endophytes in modifying insect herbivory, relatively little is know about the ways in which endophyte-infected tall fescue might be impacting nonpest insects in more natural grassland communities.

In the Midwestern United States, there have been major declines in many prairie-specialist butterflies, as well as many other important native pollinators (Swengel et al. 2011, Swengel and Swengel 2015). Generally, the causes of these declines are attributed to habitat loss and fragmentation, and to the extensive use of herbicides and pesticides in agriculture (Wright and Wimberly 2013, Vanbergen and the Insect Pollinators Initiative 2013). However, one of the more puzzling issues is the conundrum of skipper butterfly losses despite the apparent plethora of grassland habitat in some regions. Given that many skippers use grasses as host plants, the driving factor of observed declines is clearly not attributable to habitat loss. Furthermore, if the sites receive limited insecticide use, as is common in many US grasslands (United States Department of Agriculture 2003), then there must be additional factors contributing to pollinator declines. Grass skippers from the subfamily Hesperiinae are grass-eating generalists in their larval stages, yet they are failing to thrive in many grassland environments. One possible reason for their decline is that overall forage diversity and quality is changing due to increased exotic grass cover. Another potential less visible threat may be that of the endophyte toxins produced within the plant tissue of common invasive exotic pasture grasses like tall fescue. Given that several grass skippers are being proposed for listing as endangered or threatened species (Iowa Natural Resource Commission 2009, Fish and Wildlife Service 2014), it is imperative to investigate the role that altered forage quality, particularly alkaloids associated with endophyte-infected tall fescue, might be playing on these important pollinators.

The objective of this research was to to compare the effects of endophyte-infected and endophyte-free tall fescue versus a common, co-occurring cool season grass, Kentucky bluegrass (Poa pratensis) on the growth and development of tawny-edged skippers (Polites themistocles (Latreille)). While Panicum species have been reported as host plants for tawny-edged skippers in some parts of their range, their grass preferences in Iowa are presently unknown (Schlicht et al. 2007). Several sources suggest Poa pratensis as a potential host plant for this species (Scott 1986, James and Nunnallee 2011, Opler et al. 2012). Tawny-edged skippers are common residents of tallgrass prairies, but they are also frequently seen in old fields, city parks, and urban lawns. We used this butterfly because it is a native species, but much more numerous than some of the more threatened species. Larvae of $P$. themistocles are known to feed on a wide variety of grasses (Scott 1986, James and Nunnallee 2011), and they are therefore likely affected by increasing exotic grass dominance. We hypothesized that larvae grown on $\mathrm{E}+$ tall fescue would have reduced survival and reduced weight gain compared to larvae grown on E- tall fescue and KBG because of the negative effects of loline alkaloids. We also hypothesized that there would be minimal response differences between E- tall fescue and KBG. Finally, we expected that these lab-based results would provide important insights about the impacts of endophyte-infected tall fescue on the life history of prairie-dependent butterflies.

\section{Materials and Methods}

\section{Plant Material}

Three types of grass were used as treatments in this study: endophyte-infected tall fescue 'KY-31' (Schedonorus arundinaceus Schreb.) (E+), endophyte-free tall fescue 'KY-31 EF' (E-), and Kentucky bluegrass (Poa pratensis) (KBG). We chose tall fescue 'KY-31' because it is the most widespread cultivar grown in the United States (Ball et al. 1993), and it has invaded many natural areas within the tallgrass prairie ecoregion (McGranahan 2012). KBG was selected because it often co-occurs as an invasive, exotic grass with tall fescue in tallgrass prairies (Cully et al. 2003), and previous efforts rearing tawny-edged skippers (Polites themistocles) were successful on this grass (James and Nunnallee 2011). Thus, KBG served as a baseline (a known palatable species) which we could compare to E+ and E- tall fescue. Grass seeds were sourced from Dr. Tim Phillips, a grass breeder in the Department of Plant and Soil Sciences at the University of Kentucky.

Grass plugs were grown in 72-cell trays in a greenhouse. Tall fescue was seeded at a rate of 10-15 seeds per cell, whereas KBG was seeded at a higher rate (15-20 seeds per cell) due to smaller seed size. Four- to eight-week-old grass plugs were used as forage for the developing larvae.

The grass plugs were replaced for each larva on a routine basis in order to resupply forage and to avoid mold and frass build-up in each tube. The fescue grasses tended to grow more biomass in a shorter amount of time than KBG. Consequently, KBG grass plugs were smaller and needed to be replaced more frequently than tall fescue. On average, larvae feeding on KBG had their plugs replaced 6.2 times, whereas larvae feeding on the two fescue types had their plugs replaced an average of 4.6 times before they pupated. In addition, the KBG grasses were on average 4.6 wk old, whereas the fescues were usually $5.0 \mathrm{wk}$ old when they were replaced.

\section{Alkaloid, Carbon, and Nitrogen Analyses}

Aboveground samples of all three grass types at 4, 5, 6, 7, and 8 wk of age were sent to the University of Kentucky for alkaloid and carbon and nitrogen analysis. Loline and ergot alkaloid analyses were conducted using gas chromatography-mass spectrometery (GC-MS) and high performance liquid chromatography (HPLC) techniques, the same as those reported in McCulley et al. (2014). We expected alkaloid levels to differ as the plant matured (Hardy et al. 1986). The limit of detection for ergot alkaloids was $0.02 \mathrm{ppm}$ and $10 \mathrm{ppm}$ for loline alkaloids.

Percent $\mathrm{C}$ and $\mathrm{N}$ in the grass samples were assessed using a Flash Elemental Analyzer 1112 (Thermo Fischer Scientific, Inc. Waltham, $\mathrm{MA})$. From these data we were able to calculate a C:N ratio in order to obtain a simple measure of forage quality in the larval diets.

\section{Field Collection of Butterflies}

Female tawny-edged skippers can lay up to 300 eggs per year (Scott 1986). To ensure a reasonable sample size for this experiment, two assumptions were made: 1) Wild-caught butterflies will have already laid some eggs in the field, and thus fewer than half of their total eggs would be available for the experiment. We estimated very conservatively that female butterflies in captivity would lay an average of 50 
eggs per individual. 2) Regardless of treatment effect, developing larvae would have high mortality rates $(50 \%)$ at each life stage in the rearing process. Given the expected losses throughout the experiment, we aimed to collect a minimum of 25 female butterflies from the field.

Butterflies were collected 11-20 June 2014 in the Grand River Grasslands of Ringgold County, Iowa. The Grand River Grasslands region is over 28,000 ha in size and composed primarily of perennial grassland. Small parts of the region have remnant tallgrass prairies, but the rest is highly invaded with tall fescue and other exotic species, including Kentucky bluegrass. Twenty-seven female tawnyedged skippers were captured with butterfly nets. In most cases, butterflies were found in restored prairies while nectaring on red clover (Trifolium pratense) or pale purple coneflower (Echinacea pallida). All individuals were transported back to the lab in cool, dark conditions to minimize harm during two hours of travel.

\section{Insect Rearing}

Subsequent stages of the experiment were conducted in a controlled environmental chamber (Carroll Coolers Inc., model N016898,
Carroll, IA) at $25^{\circ} \mathrm{C}$ and $60 \%$ relative humidity, with a photoperiod of $16: 8$ (L:D) h.

After field collection, five to eight butterflies were placed into each oviposition chamber. Oviposition chambers were constructed using two paper cups (one stacked within the other), with mesh netting fastened to the top. Each chamber contained a live KBG plug. Artificial nectar (1 part honey to 9 parts water) was applied to cotton swabs that extended into the chamber through holes in the side of the cup. Eggs were laid on the grass, as well as virtually all surfaces of the oviposition chamber. Twenty-seven females laid a total of 1,095 eggs.

In order to manage environmental conditions and account for each individual, eggs were transferred to egg chambers to hatch. To construct egg chambers, $8 \mathrm{oz}$. plastic containers were disinfected with $75 \%$ ethanol, and lined with a damp paper towel for humidity regulation (Fig. 1). The eggs were monitored daily, and hatching larvae were transferred to $\mathrm{E}+, \mathrm{E}-$, or $\mathrm{KBG}$ grass treatments. The first larva that hatched was assigned to $\mathrm{E}+$, the second larva was assigned to $\mathrm{E}-$, and the third larva was assigned to KBG.
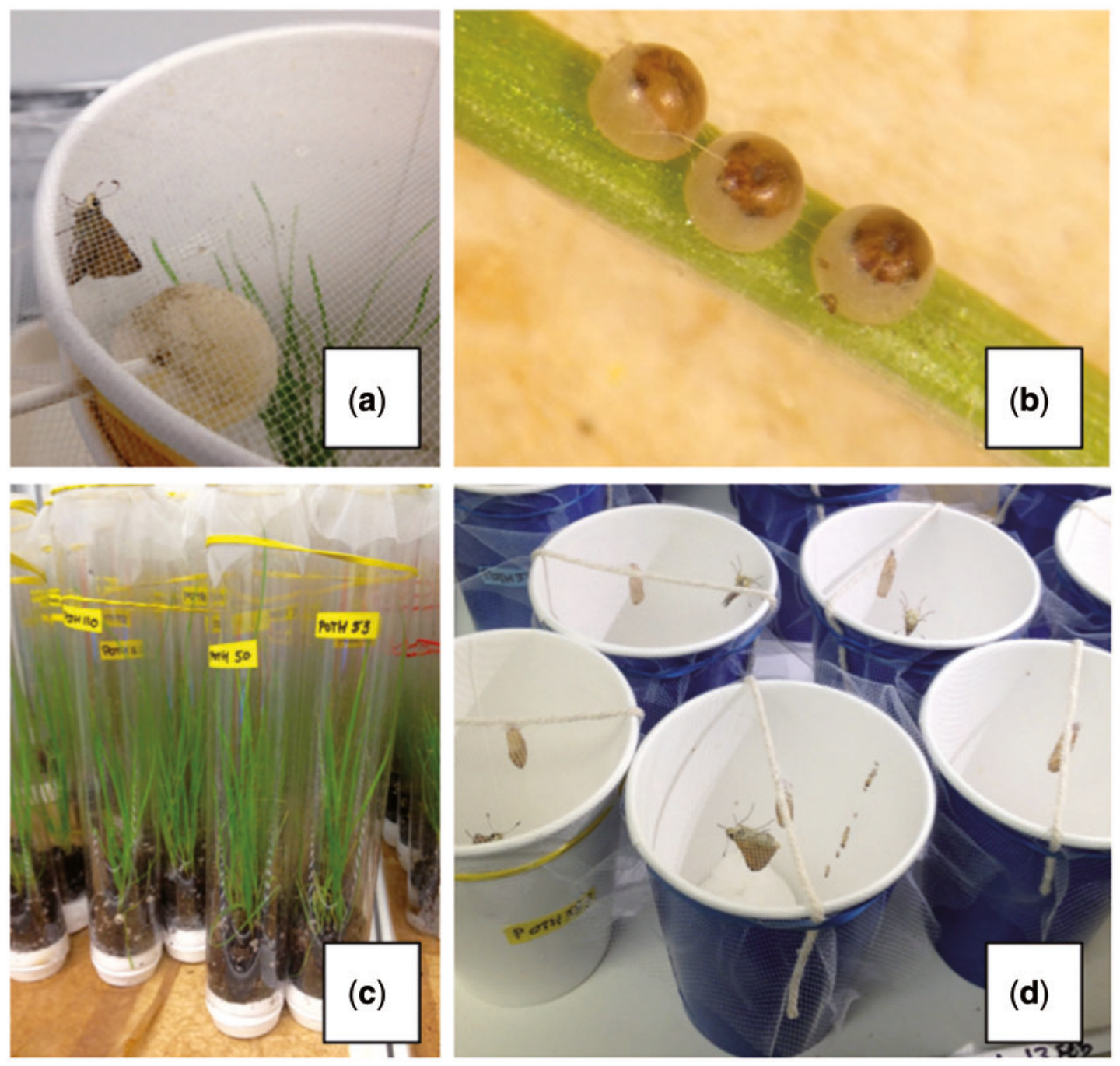

Fig. 1. (a) Oviposition chamber with female skippers, a grass host plant (Poa pratensis), and a nectar source. Mesh netting was banded to the top of each cup. (b) Incubation chamber where eggs were transferred to hatch. Most eggs were removed from the oviposition chamber with a sterilized paint brush, but some eggs resisted removal, so we cut around the egg and left a small piece of grass attached to the egg. The incubation chamber was sterilized and contained a damp paper towel for humidity regulation. (c) Polycarbonate tubes with grass treatments and independent larvae. Each tube was capped with a fine mesh netting. (d) Pupation chambers made from paper cups, mesh netting, a dampened cotton ball for localized humidity, and individual pupae affixed to twine with silicone adhesive. 
All subsequent larvae were assigned to treatments in the same order to assure equal sample size across treatments. Of the 1,095 eggs, only 617 hatched into larvae. Most larvae emerged after 7 to $9 \mathrm{~d}$.

Developing larvae were reared in T12 clear polycarbonate tubes used for shatter guards on fluorescent light bulbs (1000 Bulbs, Garland, TX). Tubes were cut to $25 \mathrm{~cm}$ lengths and capped with a fine screen to contain caterpillars. Grass plugs were inserted into the bottom of each tube and a single larva was transferred onto a blade of grass within the tube (Fig 1). Plugs were set onto paper towellined trays and watered from the bottom daily so that the plugs were damp but not saturated. All tubes were labeled with unique identification numbers so that individual larvae could be measured repeatedly over time.

The weights of individual larvae were measured every $5 \mathrm{~d}$. Beyond these routine measurements, handling of larvae was kept to a minimum and was always done with disinfected equipment. Grass plugs were removed and replaced when larvae had consumed them, or when grasses became contaminated with mold or frass.

Once pupated, individuals were removed from the tubes, measured for mass and length, and affixed to twine with a small dab of silicone adhesive on the pointed tip of the chrysalis. They were then separated and placed in individually labeled paper-cup chambers where they could eclose and yet remain contained (Fig. 1). Upon eclosion, adults were frozen for future analyses.

\section{Data Analysis}

All analyses were conducted in SAS 9.3 (SAS Institute 2011, Cary, NC). A two-way analysis of variance (ANOVA; PROC GLIMMIX) was used to test for differences in $\mathrm{C}: \mathrm{N}$ ratios and alkaloid concentration with grass treatment and age of grass samples as main effects.

A logistic, nonlinear mixed model was used to analyze the larval growth data. The model is as follows:

$$
y_{i j}=\frac{b_{1}+u_{1 i}}{1+\exp \left[-\left(\text { Time }_{i j}-b_{2}\right) / b_{3}\right]}+e_{i j}
$$

where Time $_{i j}$ is the corresponding time; $b_{1}, b_{2}$, and $b_{3}$ are the fixed effects parameters; $u_{1 i}$ is the random-effect parameter assumed to be independent and identically distributed (idd) $\mathrm{N}\left(0, \sigma^{2} \mathrm{u}\right)$; and $e_{i j}$ is the residual error assumed to be idd $\left(0, \sigma^{2} \mathrm{e}\right)$ and independent of the $u_{1}$. The growth asymptote for each treatment is defined by $b_{1}, b_{2}$ is the day(s) at which the maximum growth inflation occurred, and $b_{3}$ is the rate of growth. $Y_{i j}$ represents the response of the $j^{\text {th }}$ observation under the $i^{\text {th }}$ treatment. This model allows the maximum growth achieved $\left(b_{1}\right)$ and the rate at which each individual achieved it $\left(b_{3}\right)$ to vary based on the treatment. Model parameters were compared across treatments using contrasts.

Larval survival data were analyzed using the nonparametric Kaplan Meier model (PROC LIFETEST), which calculates the probability of survival for each treatment group and at each time point. A log rank test was used to compare the probability of survival to adulthood between the three treatments in the long-term. A Wilcoxon test was used to test for differences in survival between groups in the short-term. Individuals were considered right-censored if they developed normally and eclosed as adults; these individuals generally developed faster and "withdrew" from the study early. All other individuals died prematurely as larvae or pupae, presumably due to treatment effects.

ANOVAs were also used to compare pupal responses in days to pupation, number of days as a pupa, pupal length, and pupal weight. All data were checked for normality. A Poisson distribution was fit for age at pupation because the data were right-skewed. Means were compared using Fisher's least significant difference test, with significance set at $P=0.05$.

\section{Results}

\section{Grass Forage Quality}

The carbon to nitrogen $(\mathrm{C}: \mathrm{N})$ ratio was different across grass treatments $(F=63.04 ; \mathrm{df}=2,49 ; P<0.001)$. There was no difference between endophyte-infected and endophyte-free tall fescue, but on average, the C:N ratio for the two fescue treatments was 3.3 units higher than for Kentucky bluegrass. Low C:N ratios imply more nitrogen available per unit of carbon for feeding larvae. There were also differences in $\mathrm{C}: \mathrm{N}$ ratios among different aged cohorts of grass $(F=54.35 ; \mathrm{df}=2,49 ; P<0.001)$. Averaged across all grass treatments, C:N tended to increase with age from a ratio of 7.4 for 4 -wkold grass samples to 13.2 for 8 -wk-old samples. There was no interaction between grass treatment and age (weeks) $(F=1.29 ; \mathrm{df}=8$, 49; $P=0.27)$.

\section{Grass Alkaloid Profiles}

Alkaloid profiles consisted of various ergot and loline alkaloids (Table 1). As expected, E- tall fescue and KBG had barely detectable levels of both measured types of alkaloids; total loline levels for $\mathrm{E}$ - tall fescue were on average $13 \mathrm{ppm}$, and KBG had an average of $11 \mathrm{ppm}$. In contrast, total loline levels for $\mathrm{E}+$ tall fescue were on average $740 \mathrm{ppm}$. Consequently, we only analyzed differences in alkaloid concentration across different age classes in $\mathrm{E}+$ plant material (Table 1). E + tall fescue had high levels of loline alkaloids, but unexpectedly low levels of ergot alkaloids. Interestingly, the loline alkaloid levels were consistently higher in younger $\mathrm{E}+$ samples than in older samples. Total loline levels in 4-wk-old $\mathrm{E}+$ material were seven times higher than in 8-wk-old $\mathrm{E}+$ material.

\section{Skipper Responses}

Larval growth asymptotes did not differ among the three grass treatments for weight gain (Table 2). The average maximum body weight across treatments was estimated at 0.26 ( $\pm 0.01 \mathrm{SE}$ ) grams (Fig. 2).

Table 1. Alkaloid concentrations of endophyte-infected tall fescue above-ground plant material at different ages (weeks)

\begin{tabular}{|c|c|c|c|c|c|c|c|}
\hline \multirow[t]{3}{*}{ Age } & \multicolumn{7}{|c|}{ Alkaloids } \\
\hline & \multicolumn{3}{|c|}{ Ergovalines $^{b}$} & \multicolumn{4}{|l|}{ Lolines $^{c}$} \\
\hline & $\mathrm{EV}^{a}$ & EVI & Total erg & NANL & NFL & NAL & Total lol \\
\hline 4 & 0.026 & 0.016 & 0.042 & $86.4 \mathrm{a}$ & $1308.2 \mathrm{a}$ & $510.2 \mathrm{a}$ & $1904.8 \mathrm{a}$ \\
\hline 5 & 0.106 & 0.058 & 0.164 & $32.2 b$ & $428.0 \mathrm{~b}$ & $225.8 \mathrm{~b}$ & $686.2 \mathrm{~b}$ \\
\hline 6 & 0.026 & 0.002 & 0.026 & $23.2 b c$ & $315.8 \mathrm{bc}$ & $189.2 \mathrm{bc}$ & $528.2 \mathrm{bc}$ \\
\hline 7 & 0.026 & 0.000 & 0.028 & $16.2 \mathrm{c}$ & $205.5 \mathrm{c}$ & $127.4 \mathrm{~cd}$ & $348.8 \mathrm{~cd}$ \\
\hline \multirow[t]{2}{*}{8} & 0.016 & 0.000 & 0.010 & $9.8 \mathrm{c}$ & $136.0 \mathrm{c}$ & $87.6 \mathrm{~d}$ & $233.2 \mathrm{~d}$ \\
\hline & NS & NS & NS & $* * *$ & $* * *$ & $* * *$ & $* * *$ \\
\hline
\end{tabular}

Units are in parts per million (ppm).

${ }^{a}$ Means within a column followed by the same letter are not significantly different $(P \leq 0.05)$ according to Fisher's protected LSD. $P<0.05$; **, $P<0.01 ; * * *, P<0.001$; NS, not significant; values in columns were tested for significance.

${ }^{b}$ EV, ergovaline; EVI, ergovalinine; total erg, ergovaline + ergovalinine.

${ }^{c}$ NANL, $\mathrm{N}$-acetyl norloline; NFL, $\mathrm{N}$-formyl loline; NAL, $\mathrm{N}$-acetyl loline; total lol, NANL + NFL + NAL. 
The rate of weight gain differed significantly among all three treatments (Fig. 2).

Overall, the long-term probability of larval survival did not differ among treatments according to the $\log$ rank survival analysis $(P=0.0918$; Fig. 3). Larvae that fed on $\mathrm{E}+$ and $\mathrm{E}-$ tall fescue had nearly identical long-term probabilities of survival, while those that fed on KBG had a higher survival probability during the first 40 days of development. A Wilcoxon test showed that there were differences in the short-term survival probabilities across treatments $(P=0.0022)$. Only $36.6 \%$ of the individuals reared on KBG died prematurely $(n=194)$, compared with $53.2 \%$ for $\mathrm{E}-$ tall fescue $(n=205)$ and $53.4 \%$ for $\mathrm{E}+$ tall fescue $(n=206)$.

Similar to larval growth and survival responses, pupae reared on KBG developed faster and had greater overall biomass than individuals reared on the two fescue treatments (Table 3). Individuals reared on KBG pupated, on average, $10 \mathrm{~d}$ earlier than those reared on tall fescue. There was no difference between $\mathrm{E}+$ and

Table 2. Growth means and standard errors in terms of weight gain (g) from nonlinear mixed effects model of tawny-edged skipper larvae grown on three different grass diets: Kentucky bluegrass $(K B G)$, endophyte-infected tall fescue $(E+)$, and endophyte-free tall fescue (E-)

\begin{tabular}{llcc}
\hline Treatment & $\begin{array}{l}\text { Growth } \\
\text { asymptote }\left(b_{1}\right)\end{array}$ & $\begin{array}{l}\text { Day of max } \\
\text { growth }\left(b_{2}\right)\end{array}$ & $\begin{array}{l}\text { Rate of } \\
\text { growth }\left(b_{3}\right)\end{array}$ \\
\hline E+ & $0.265 \pm 0.009$ & $29.1 \pm 0.30$ & $5.03 \pm 0.16$ \\
E- & $0.263 \pm 0.009$ & $29.7 \pm 0.36$ & $5.59 \pm 0.19$ \\
KBG & $0.266 \pm 0.008$ & $22.6 \pm 0.19$ & $3.75 \pm 0.11$ \\
Contrasts & & & \\
E+vs. E- & 0.8481 & 0.1912 & 0.0209 \\
KBG vs. E+ & 0.9716 & $<0.0001$ & $<0.0001$ \\
KBG vs. E- & 0.8115 & $<0.0001$ & $<0.0001$ \\
\hline
\end{tabular}

$P$-values are presented for the contrasts of model parameters, with significant contrasts bolded.
E- treatments in days to pupation or days as a pupa, though differences were found in pupal length and weight. E+ pupae averaged $0.4 \mathrm{~mm}$ longer and $9.9 \mathrm{mg}$ heavier than E- pupae (Table 3). Pupae from skippers fed $\mathrm{KBG}$ were the largest, averaging 0.5 and $0.9 \mathrm{~mm}$ longer, and 13.6 and $23.5 \mathrm{mg}$ heavier, than $\mathrm{E}+$ and $\mathrm{E}-$, respectively (Table 3).

\section{Discussion}

Kentucky bluegrass and tall fescue have become dominant components of native U.S. tallgrass prairie ecosystems (Spyreas et al. 2001, Cully et al. 2003, Tunnell et al. 2004) and may negatively impact food webs, grassland community dynamics, and ecosystem processes (Rudgers and Clay 2007; McGranahan et al. 2012, 2015). Our study is the first to examine the effects of these exotic grasses on native butterflies and to explore the role of fungal endophyte infection in tall fescue. We found that tawny-edged skippers had enhanced growth, development, and survival on KBG versus tall fescue and that endophyte effects were limited.

Because numerous studies have described the antiherbivore effects of endophyte-infected tall fescue on pest insects of turf and forage grasses (Ball et al. 2006, Cheplick and Faeth 2009), we hypothesized that alkaloid-containing $\mathrm{E}+$ tall fescue would be more deleterious to the development and survival of tawny-edged skippers when compared to alkaloid-free E- tall fescue and KBG. Contrary to our predictions, presence of the tall fescue endophyte did not affect growth and survival of larvae compared to E- tall fescue (Fig. 2 and 3). This result is surprising given that loline alkaloid levels were on average 57 times higher in $\mathrm{E}+$ than $\mathrm{E}$ - tall fescue samples. Our results contrast with much of the literature that establishes Epichloë-associated loline alkaloids as toxic to invertebrate herbivores (Siegel et al. 1990, Bush et al. 1993, Wilkinson et al. 2000). However, there is some controversy about the role of endophyteproduced alkaloids in insect deterrence, as many people have also reported variability in insect responses (Saikkonen et al. 1998,

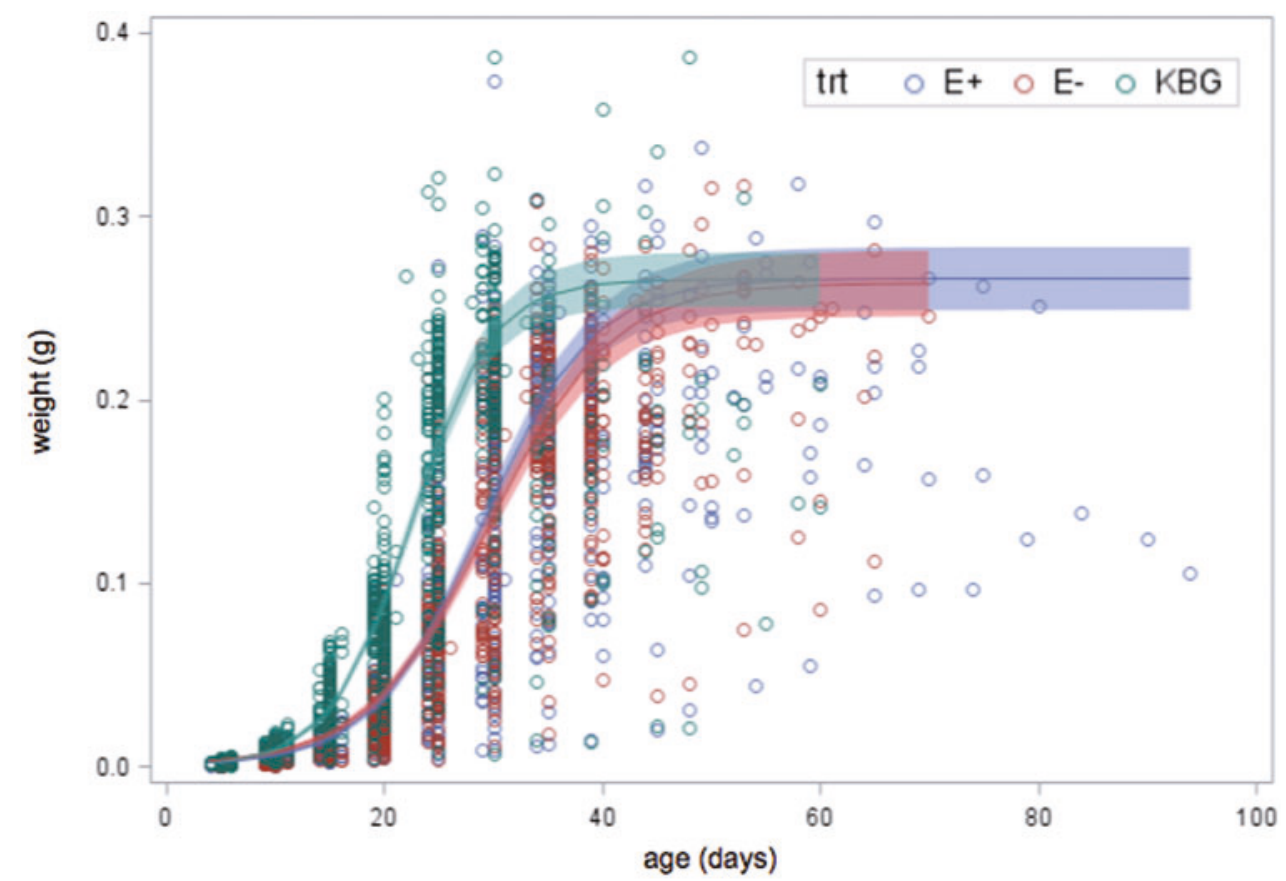

Fig. 2. Estimated growth curve of larvae body weight over time for three different grass diets: Kentucky bluegrass (KBG), endophyte-infected tall fescue (E + ), and endophyte-free tall fescue ( $E-)$. 


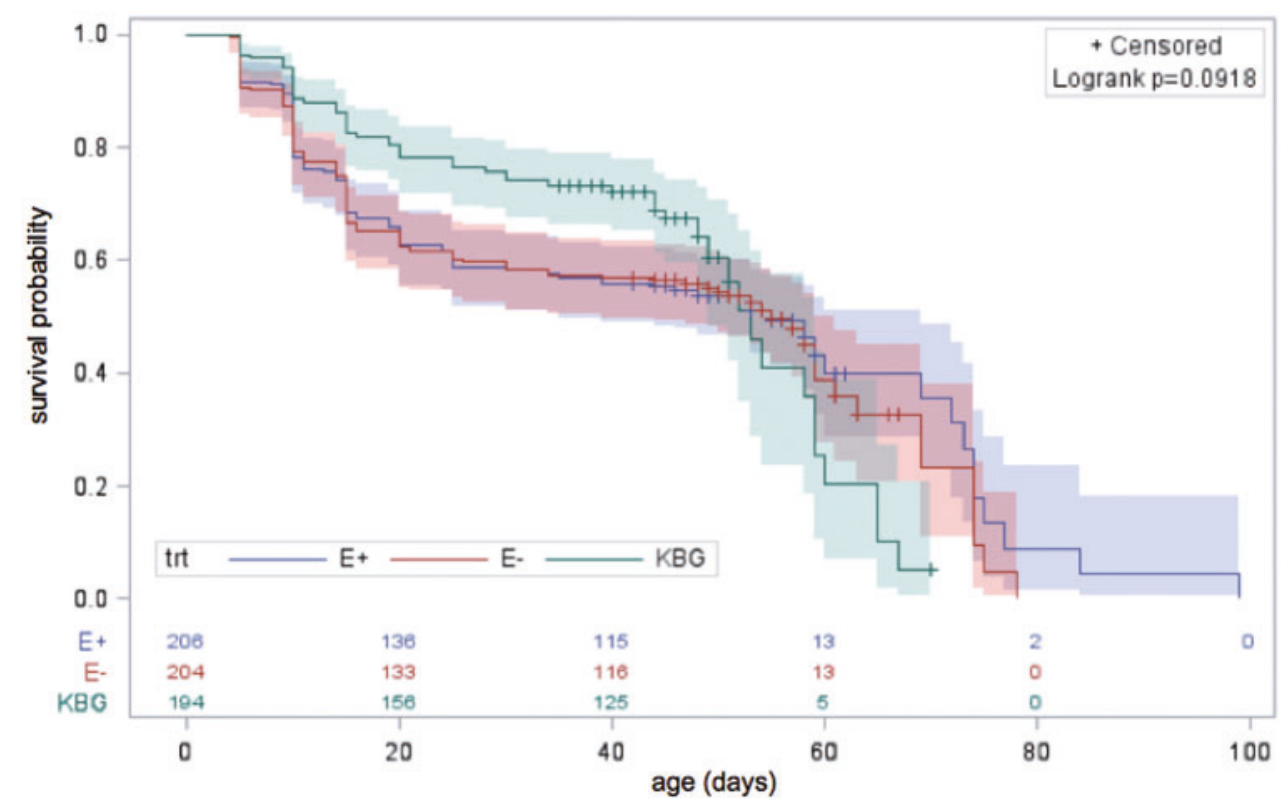

Fig. 3. Kaplan Meier survival probability over time (days) for caterpillars feeding on three different diets: Kentucky bluegrass (KBG), endophyte-infected tall fescue $(E+)$, and endophyte-free tall fescue $(E-)$. The shaded areas represent $95 \%$ confidence limits. Values on the bottom of the graph represent the number of individuals remaining in each of the three treatments at any point in time. Individuals were considered censored if they developed normally, pupated, and eclosed as adults. A log rank test was used to compare the probability of survival to adulthood between the three treatments in the long-term.

Table 3. Average pupal measurements and standard errors of individuals reared on three different grass diets: endophyte-infected tall fescue $(E+)$, endophyte-free tall fescue $(E-)$, or Kentucky bluegrass (KBG)

\begin{tabular}{llcccc}
\hline Treatment & $n$ & Days to pupation & Days as pupa & Pupal length (mm) & Pupal weight (mg) \\
\hline E+ & 105 & $43.0 \pm 0.6 \mathrm{a}$ & $8.8 \pm 0.1$ & $17.3 \pm 0.09 \mathrm{a}$ & $171.2 \pm 2.3 \mathrm{a}$ \\
E- & 112 & $43.8 \pm 0.6 \mathrm{a}$ & $8.9 \pm 0.1$ & $16.9 \pm 0.09 \mathrm{~b}$ & $161.3 \pm 2.2 \mathrm{~b}$ \\
KBG & 140 & $34.4 \pm 0.5 \mathrm{~b}$ & $9.0 \pm 0.1$ & $17.8 \pm 0.08 \mathrm{c}$ & $184.8 \pm 2.0 \mathrm{c}$ \\
& & $<0.0001$ & 0.7216 & $<0.0001$ & $<0.0001$ \\
\hline
\end{tabular}

Means containing the same letter are not significantly different from one another at alpha $=0.05 . P$-values are shown with significant differences bolded.

Cheplick and Faeth 2009). Our findings illustrate that endophyteproduced loline alkaloids, at the levels seen in our study, are apparently not toxic to tawny-edged skippers.

Several researchers have used Lepidoptera pest species (e.g., Spodoptera frugiperda) to quantify the effects of fungal endophytes on invertebrate herbivores. Our results both support and contradict this literature. For example, Boning and Bultman (1996) found that $S$. frugiperda larvae weighed less and took longer to develop after feeding on $\mathrm{E}+$ tall fescue vs. E- plant material. In contrast, Bultman and Bell (2003) found the surprising result that $S$. frugiperda larvae had enhanced performance on E+ versus E- tall fescue. Our findings run counter to both of these results; for most parameters, our skipper larvae performed similarly on E+ versus E- tall fescue, but the larvae on $\mathrm{E}+$ tall fescue had a slightly slower growth rate than larvae reared on E- tall fescue (Table 2). Despite having dissimilar larval responses compared to those reported by others, our pupal responses concur with past research. On average, our E+ pupae were larger than E- pupae (Table 2), which is comparable to results reported by Boning and Bultman (2006). Because pupal mass in Lepidoptera has been strongly associated with fitness (Campbell 1962, Hough and Pimentel 1978, Loewy et al. 2013), the endophyte might actually be conferring a benefit to these herbivores, but additional research is necessary to further explore this possibility.
One explanation for our unique results could be that native, grass-eating invertebrate herbivores, such as the tawny-edged skipper, may have evolved in an environment with alkaloid-producing fungal endophytes (Tibbets and Faeth 1999). Research has shown that endophyte-infection is seen in $\sim 2,000$ grass host species, especially among cool-season, $C_{3}$ grasses (Leuchtmann 1992, Clay and Schardl 2002, Rudgers et al. 2009, Crawford et al. 2010). Very few researchers have tested for herbivore resistance in native endophytegrass associations, but there is evidence that endophytic fungi may also confer antiherbivore benefits to native grasses (Afkhami and Rudgers 2009, Crawford et al. 2010). This may explain why skipper larvae performed better than expected on $\mathrm{E}+$ tall fescue.

We also assumed that larvae reared on E- tall fescue and KBG would have similar growth and survival rates because, without alkaloids, the forage quality of these two grass treatments would be comparable from the skipper perspective. The results indicated that KBG provided higher forage quality for tawny-edged skipper larvae compared to both $\mathrm{E}+$ and $\mathrm{E}$ - tall fescue. $\mathrm{KGB}$ material had a lower $\mathrm{C}: \mathrm{N}$ ratio and supported greater survival rates in the first 40 days of development (Fig. 3) than the fescue material. Larvae in this treatment grew faster, larger, and with less variability (Fig. 3). Pupae reared on KBG were also distinctly heavier than pupae reared on either fescue. The difference in $\mathrm{C}: \mathrm{N}$ ratios might be explained by the fact that our KBG grass plugs grew less biomass over time than the 
fescue plugs. Consequently, the KBG plugs needed to be replaced more frequently, and the plugs were younger, and possibly more tender when they were being consumed.

One possible biological implication of the differences that we observed between KBG and both fescue treatments may have to do with age to pupation and rate of larval growth. Short development times and high growth rates are generally considered beneficial for insects (Nylin and Gotthard 1998) because prolonged development results in more exposure to predators and parasites, which could increase juvenile mortality (Sibly and Calow 1986). We suspect that a shorter age to pupation on KBG would have a positive effect on survival in a field setting, but additional research would be needed to confirm this as an advantage.

The life history of many grass skippers is still poorly known (Bouseman et al. 2006). For example, it is unclear how skippers and other grassland-dependent butterflies interact with exotic grasses, such as KBG and tall fescue, in the wild. To our knowledge, no one has observed tall fescue as a host plant for grasseating butterfly species in North America, and only a couple of butterfly species have been observed to oviposit on KBG in a natural setting (Graves and Shapiro 2003, Beyer and Schultz 2010). For many skipper species, scientists know which grass species larvae prefer to eat in a lab setting, but very few observations have been made of actual oviposition events and larval feeding in the wild (James and Nunnallee 2011). Nevertheless, it would have been beneficial to include a broader suite of grass treatments to quantify developmental responses on co-occurring native grasses like little bluestem (Schizachyrium scoparium)-a known host plant for some threatened grass skippers-and crabgrass (Dichanthelium clandestinum) - a reported host plant for Polites themistocles (Scott 1986). Many of the threatened and endangered skippers such as the Dakota skipper (Hesperia dacotae) and Poweshiek skipperling (Oarisma poweshiek) have reportedly been found feeding on warm-season grasses, which can also host fungal endophyte symbionts (Ghimire et al. 2011). Future research could compare our results with those of other grass-eating butterflies such as species from the sub-family Satyrinae.

Our results illustrate that exotic grasses vary in their effects on insect forage quality. In the case of the tawny-edged skipper, tall fescue, regardless of endophyte infection status, provided lower quality forage than KBG. Tall fescue may thus effectively contribute to habitat loss by reducing forage quality, as well as decreasing overall plant community richness and diversity and altering grassland successional dynamics (Clay and Holah 1999, Rudgers and Clay 2007). Our results do not provide direct evidence that endophyte-produced loline alkaloids contribute to grass skipper declines. In fact, skipper pupae were larger on E+ vs. E- tall fescue, suggesting a possible benefit of alkaloid consumption. Further research exploring the fitness consequences of alkaloid consumption for this butterfly, as well as additional native lepidopteran pollinators, seems warranted. In addition, research exploring other possible causes of grass skipper decline, including the effects of pesticide drift, and habitat modifications, as well as oviposition habitat selection and host plant preference in the wild, would be useful. Our research has important implications for wildlife biologists, turf superintendents, and grassland restoration managers that manage areas with exotic invasive cool-season grasses. It highlights the fact that beyond the total number of acres restored, grassland composition, and particularly exotic species composition, is an important factor governing insect forage quality and should be considered in efforts that seek to improve habitat for pollinators and other native insects.

\section{Acknowledgments}

We are grateful for technical assistance provided by Nathan Brockman and Anita Westphal of Reiman Gardens, as well as seed materials from Tim Phillips and lab measurements conducted by Huihua Ji and A.E. Carlisle at the University of Kentucky. We also thank Rhea Waldman and Anna Holtermann for their work in the field and the lab. Finally, we thank Lendie Follet of Iowa State University for assistance with statistical models. The Nature Conservancy provided partial support for this work through the Nebraska Chapter's J.E. Weaver Competitive Grants Program. The Lois H. Tiffany Scholarship at Iowa State University provided additional financial support. Lastly, we thank the Leopold Center for Sustainable Agriculture for their role in facilitating this collaboration.

\section{References Cited}

Afkhami, M. E., and J. A. Rudgers. 2009. Endophyte-mediated resistance to herbivores depends on herbivore identity in the wild grass Festuca subverticillata. Environ. Entomol. 38: 1086-1095.

Baldauf, M. W., W. J. Mace, and D. S. Richmond. 2011. Endophyte-mediated resistance to black cutworm as a function of plant cultivar and endophyte strain in tall fescue. Environ. Entomol. 40: 639-647.

Ball, D., J. F. Pedersen, and G. D. Lacefield. 1993. The tall-fescue endophyte. Am. Sci. 81: 370-379.

Ball, O. J., T. A. Coudron, B. A. Tapper, D. Trently, L. P. Bush, K. D. Gwinn, A. J. Popay, O. J. Ball, and E. Davies. 2006. Importance of host plant species, Neotyphodium endophyte isolate, and alkaloids on feeding by Spodoptera frugiperda (Lepidoptera: Noctuidae). J. Econ. Entomol. 99: 1462-1473.

Beyer, L. J., and C. B. Schultz. 2010. Oviposition selection by a rare grass skipper Polites mardon in montane habitats: Advancing ecological understanding to develop conservation strategies. Biol. Conserv. 143: 862-872.

Blankenship, J. D., M. J. Spiering, H. H. Wilkinson, F. F. Fannin, L. P. Bush, and C. L. Schardl. 2001. Production of loline alkaloids by the grass endophyte, Neotyphodium uncinatum, in defined media. Phytochemistry 58: 395-401.

Bouseman, J. K., J. G. Sternburg, and J. R. Wiker. 2006. Field guide to the skipper butterflies of Illinois. Illinois Natural History Survey, Champaign.

Braman, S. K., R. R. Duncan, M. C. Engelke, W. W. Hanna, K. Hignight, and D. Rush. 2002. Grass species and endophyte effects on survival and development of fall armyworm (Lepidoptera: Noctuidae). J. Econ. Entomol. 95: 487-492.

Bultman, T. L., and G. D. Bell. 2003. Interaction between fungal endophytes and environmental stressors influences plant resistance to insects. Oikos 1: 182-190.

Bush, L. P., F. F. Fannin, M. R. Siegel, D. L. Dahlman, and H. R. Burton. 1993. Chemistry, occurrence and biological effects of saturated pyrrolizidine alkaloids associated with endophyte-grass interactions. Agric. Ecosyst. Environ. 44: 81-102.

Ceballos, G., A. Davidson, R. List, J. Pacheco, P. Manzano-Fischer, G. SantosBarrera, and J. Cruzado. 2010. Rapid decline of a grassland system and its ecological and conservation implications. PLoS ONE 5.

Cheplick, G. P., and S. Faeth. 2009. Ecology and evolution of the grassendophyte symbiosis. Oxford University Press, New York, NY.

Clay, K. 1989. Clavicipitaceous endophytes of grasses: their potential as biocontrol agents. Mycol. Res. 92: 1-12.

Clay, K., and J. Holah. 1999. Fungal endophyte symbiosis and plant diversity in successional fields. Science (80-.). 285: 1742-1744.

Clay, K., and C. Schardl. 2002. Evolutionary origins and ecological consequences of endophyte symbiosis with grasses. Am. Nat. 160: S99-S127.

Crawford, K. M., J.M. Land, and J. A. Rudgers. 2010. Fungal endophytes of native grasses decrease insect herbivore preference and performance. Oecologia 164: 431-444.

Cully, A. C., J. F. Cully, and R. D. Hiebert. 2003. Invasion of exotic plant species in tallgrass prairie fragments. Conserv. Biol. 17: 990-998.

Fish and Wildlife Service. 2014. 50 CFR Part 17: Endangered and threatened wildlife and plants; threatened species status for dakota skipper and 
endangered species status for poweshiek skipperling. Fed. Regist. 79: 63672-63748.

Ghimire, S. R., N. D. Charlton, J. D. Bell, Y. L. Krishnamurthy, and K. D. Craven. 2011. Biodiversity of fungal endophyte communities inhabiting switchgrass (Panicum virgatum $\mathrm{L}$.) growing in the native tallgrass prairie of northern Oklahoma. Fungal Divers. 47: 19-27.

Goldson, S. L., S. D. Wratten, C. M. Ferguson, P. J. Gerard, B.I.P. Barratt, S. Hardwick, M. R. McNeill, C. B. Phillips, A. J. Popay, J. M. Tylianakis, et al. 2014. If and when successful classical biological control fails. Biol. Control 72: 76-79.

Grant, T. A., B. Flanders-Wanner, T. L. Shaffer, R. K. Murphy, and G. A. Knutsen. 2009. An emerging crisis across northern prairie refuges: Prevalence of invasive plants and a plan for adaptive management. Ecol. Restor. 27: 58-65.

Graves, S. D., and A. M. Shapiro. 2003. Exotics as host plants of the California butterly fauna. Biol. Conserv. 110: 413-433.

Hardy, T. N., K. Clay, and A. M. Hammond. 1986. Leaf age and related factors affecting endophyte-mediated resistance to fall armyworm (Lepidoptera, Noctuidae) in tall fescue. Environ. Entomol. 15: 1083-1089.

Herkert, R., D. W. Sample, and R. E. Warner. 1995. Management of Midwestern grassland landscapes for the conservation of migratory birds. In F. Thompson, III (Ed.), North central forest experiment station USDA forest service, Proceedings of a symposium held December 5, 1995, Detroit, MI.

Hobbs, R. J., E. Higgs, and J. A. Harris. 2009. Novel ecosystems: implications for conservation and restoration. Trends Ecol. Evol. 24: 599-605.

Hoveland, C. S. 1993. Importance and economic significance of the Acremonium endophytes to performance of animals and grass plant. Agric. Ecosyst. Environ. 44: 3-12.

Iowa Natural Resource Commission. 2009. Iowa's threatened and endangered species program. (https://www.legis.iowa.gov/docs/ACO/chapter/571.77. pdf) (accessed 10 January 2014).

James, D. G., and D. Nunnallee. 2011. Life histories of cascadia butterflies. Oregon State University Press, Corvallis.

Jensen, J. G., A. J. Popay, and B. A. Tapper. 2009. Argentine stem weevil adults are affected by meadow fescue endophyte and its loline alkaloids. New Zeal. Plant Prot. Soc. 62: 12-18.

Jonas, J. L., M. R. Whiles, and R. E. Charlton. 2002. Aboveground invertebrate responses to land management differences in a central Kansas grassland. Environ. Entomol. 31: 1142-1152.

Keathley, C. P., and D. A. Potter. 2012. Arthropod abundance in tall fescue, Lolium arundinaceum, pastures containing novel "safe" endophytes. J. Appl. Entomol. 136: 576-587.

Leuchtmann, A. 1992. Systematics, distribution, and host specificity of grass endophytes. Nat. Toxins. 1: 150-162.

Leuchtmann, A., C. W. Bacon, C. L. Schardl, J. F. White and M. Tadych. 2014. Nomenclatural realignment of Neotyphodium species with genus Epichloë. Mycologia. 106: 202-215.

Loewy, K. J., A. L. Flansburg, K. Grenis, M. K. Kjeldgaard, J. McCarty, L. Montesano, J. Vernick, and S. M. Murphy. 2013. Life history traits and rearing techniques for fall webworms (Hyphantria cunea Drury) in Colorado. J. Lepid. Soc. 67: 196-205.

McCulley, R. L., L. P. Bush, A. E. Carlisle, H. Ji, and J. A. Nelson. 2014. Warming reduces tall fescue abundance but stimulates toxic alkaloid concentrations in transition zone pastures of the U.S. Front. Chem. 2: 1-14.

McGranahan, D. A., D. M. Engle, S. D. Fuhlendorf, J. R. Miller, and D. Debinski. 2012. An invasive cool-season grass complicates prescribed fire management in a native warm-season grassland. Nat. Areas J. 32: 208-214.

McGranahan, D. A., D. M. Engle, J. T. Mulloy, J. R. Miller, and D. M. Debinski. 2015. Land-use history and an invasive grass affect tallgrass prairie sedge community composition. Appl. Veg. Sci. 18: 209-219.

Nylin, S., and K. Gotthard. 1998. Plasticity in life-history traits. Annu. Rev. Entomol. 43: 63-83.
Opler, P. A., K. Lotts, and T. Naberhaus. 2012. Tawny-edged skipper, Polites themistocles. Butterflies Moths North Am. (http://www.butterfliesandmoths.org/species/Polites-themistocles) (accessed 13 August 2015).

Parr, C. L., C.E.R. Lehmann, W. J. Bond, W. A. Hoffmann, and A. N. Andersen. 2014. Tropical grassy biomes: misunderstood, neglected, and under threat. Trends Ecol. Evol. 29: 205-213.

Popay, A. J., and S. A. Bonos. 2005. Biotic responses in endophytic grasses, pp. 163-185. In C. A. Roberts, C. P. West, and D. E. Spiers (eds.), Neotyphodium cool. grasses. Blackwell Publishing, Ames, Iowa.

Raman, A., W. Wheatley, and A. Popay. 2012. Endophytic fungus-vascular plant-insect interactions. Environ. Entomol. 41: 433-47.

Roberts, C., and J. Andrae. 2004. Tall fescue toxicosis and management. Crop Manag. 3.

Rudgers, J. A., and K. Clay. 2007. Endophyte symbiosis with tall fescue: How strong are the impacts on communities and ecosystems? Fungal Biol. Rev. 21: 107-124.

Rudgers, J. A., M. E. Afkhami, M. A. Rúa, A. J. Davitt, S. Hammer, and V. M. Huguet. 2009. A fungus among us: Broad patterns of endophyte distribution in the grasses. Ecology 90: 1531-1539.

Saikkonen, K., S. H. Faeth, M. Helander, and T. J. Sullivan. 1998. Fungal endophytes: A continuum of interactions with host plants. Annu. Rev. Ecol. Syst. 29: 319-343.

Saikkonen, K., P. Lehtonen, M. Helander, J. Koricheva, and S. H. Faeth. 2006. Model systems in ecology: Dissecting the endophyte-grass literature. Trends Plant Sci. 11: 428-433.

Samson, F., and F. Knopf. 1994. Prairie conservation in North America. Bioscience 44: 418-421.

Schlicht, D., J. Downey, and J. Nekola. 2007. The butterflies of Iowa. University of Iowa Press, Iowa City.

Scott, J. A. 1986. The butterflies of North America: A natural history and field guide. Stanford University Press, Stanford.

Sibly, R., and P. Calow. 1986. Why breeding earlier is always worthwhile. J. Theor. Biol. 123: 311-319.

Siegel, M. R., G. C. Latch, L. P. Bush, F. F. Fannin, D. D. Rowan, B. A. Tapper, C. W. Bacon, and M. C. Johnson. 1990. Fungal endophyte-infected grasses: Alkaloid accumulation and aphid response. J. Chem. Ecol. 16: 3301-3315.

Swengel, A. B., and S. R. Swengel. 2015. Grass-skipper (Hesperiinae) trends in midwestern USA grasslands during 1988-2013. J. Insect Conserv. 19: 279292.

Swengel, S. R., D. Schlicht, F. Olsen, and A. B. Swengel. 2011. Declines of prairie butterflies in the midwestern USA. J. Insect Conserv. 15:327-339.

Tibbets, T. M., and S. H. Faeth. 1999. Neotyphodium endophytes in grasses: Deterrents or promoters of herbivory by leaf-cutting ants? Oecologia 118: 297-305.

United States Department of Agriculture, N.R.C.S. 2003. National Range and Pasture Handbook. (http://www.nrcs.usda.gov/wps/portal/nrcs/detail/national/landuse/rangepasture/?cid=stelprdb1043084) (accessed 7 August 2015).

Vanbergen, A. J., and the Insect Pollinators Initiative. 2013. Threats to an ecosystem service: pressures on pollinators. Front. Ecol. Environ. 11: 251-259.

Veldman, J. W., and F. E. Putz. 2011. Grass-dominated vegetation, not species-diverse natural savanna, replaces degraded tropical forests on the southern edge of the Amazon Basin. Biol. Conserv. 144: 1419-1429.

Veldman, J. W., E. Buisson, G. Durigan, G. W. Fernandes, S. Le Stradic, G. Mahy, D. Negreiros, G. E. Overbeck, R. G. Veldman, N. P. Zaloumis, et al. 2015. Toward an old-growth concept for grasslands, savannas, and woodlands. Front. Ecol. Environ. 13: 154-162.

Wilkinson, H. H., M. R. Siegel, J. D. Blankenship, A. C. Mallory, L. P. Bush, and C. L. Schardl. 2000. Contribution of fungal loline alkaloids to protection from aphids in a grass-endophyte mutualism. Mol. Plant. Microbe. Interact. 13: 1027-1033.

Wright, C. K., and M. C. Wimberly. 2013. Recent land use change in the Western Corn Belt threatens grasslands and wetlands. Proc. Natl. Acad. Sci. 110: 4134-4139. 